\title{
法律の適用・解釈における保険概念の 役割
}

後藤元

\section{ロアブストラクト}

法律の適用・解釈において保険概念に関する議論が意味を持つ局面として は，「保険」であることが法規定の適用要件になっているため，ある取引が まさに「保険」取引であるのか否かということが問題となる場合（Ex.保険 法・保険業法・法人税法の損金算入）と，当該規定の要件に「保険」という 概念は含まれていないが，ある取引に当該規定を適用するに際して，当該取 引が保険取引であることがどのような影響を与えるかということが問題とな る場合 $(\mathrm{Ex}$.独占禁止法の課徴金額の算定）がある。いずれの場合について も，「保険」という取引・制度をどう捉えるかという問題は重要なものであ るが，その議論から個々の法規定の適用について直接結論を導きうるとは限 らず，当該法規の趣旨・効果を踏まえて当該法規をいかなる場合にどのよう に適用すべきかという観点からの検討が必要である。

\section{ロキーワード}

保険概念, 税法, 独占禁止法

\section{I 。はじめに}

法解釈論において，保険とは何かということに関する議論が意味を持ちそ うな局面は，その適用が問題となっている法規定の性質によって，大きく二

*平成21年10月25日の日本保険学会大会 (龍谷大学) 報告による。 / 平成 22 年 1 月 12 日原稿受領。 
法律の適用・解釈における保険概念の役割

つに分けることができると思われる1)。

すなわち，第一に，「保険」であることが当該規定の適用要件になってい る場合がある。ここでは，ある取引がまさに「保険」取引であるのか否か， ということが問題となる ${ }^{2)}$ 。第二に，当該規定の要件に「保険」という概念 は含まれていないが，ある取引に当該規定を適用するに際して，当該取引が 保険取引であることがどのような影響を与えるかということが問題となる場 合もある。

第一の局面で問題となる法律としては，もちろん保険契約法（保険法）と 保険監督法（保険業法）がある。また，租税法においても，法律の文言上， 「保険」という要件が存在するわけではないが，課税要件を定めるに当たっ て私法上の概念に依拠することが多いため，問題となる取引が保険であるの かどうかが問題となり得る。これまで問題となった具体例としては，クレジ ツトデリバティブや天候デリバティブなどが挙げられよう。他方，第二の局 面については，これまでに問題となった具体例としては，独占禁止法がカル テル行為に対する課徴金の額を業者の売上額を基準として定めているところ， 保険料についてカルテル行為を行った保険会社の売上額とは何かということ がある。この事案では，取引内容自体は，典型的な保険であった。

以下では，第一の局面については，典型的な保険取引ではない夕イプの取 引や典型的な保険取引と類似しているが保険契約としては構成されていない 取引が保険契約法・保険監督法・租税法上どのように扱われるかという問題 を検討し，第二の局面については，保険学等における「保険」の本質・機能 に関する議論が法律の解釈にどのような影響を与えるかという問題の例とし て，上記の独占禁止法と保険会社の売上額の問題を検討することにしたい。 なお，これらの検討においては，それぞれの法律における「保険」概念の確

1）なお，この分類はあくまで整理のためのものであり，結論において違いを導 くことを意図したものではない。

2）山下友信「保険・保険デリバティブ・賭博ーリスク移転取引のボーダー」江 頭憲治郎＝増井良啓編『市場と組織』227頁（東京大学出版会，2005年）参照。 
保険学雑誌 第 609 号

立や，「保険」と分類される取引の特徵の導出を目指しているわけではない。 あくまで，具体的取引についての具体的な規定の適用の是非の検討が目的で あり，それに際して，法律学以外の領域でなされてきた議論を法律解釈に当 たってどのように受けとめるかということが問題となる。換言すれば，法律 の適用・解釈において「保険」という概念がどのような役割を果たしており， そして保険とは何か，その特徵は何かということを論ずることにどのような 意味があるのかということを検討することになる。

\section{II. 典型的な保険以外の取引と保険契約法・保険監督法・租税法の適用}

\section{1.はじめに}

保険とは何であるか，保険の本質は何かという問題は，古くから膨大な議 論が蓄積されている。ここでは，近時の文献における議論を紹介するにとど めざるを得ない。

たとえば，吉澤卓哉は，リスクヘッジャーに存在する経済的リスクをリス クテイカーに移転すること，同質で相互独立のリスクを多数集積すること， リスクヘッジャーによるプレミアムの支払いによってリスクが各リスクヘッ ジャーに分散され，個々のへッジャーの不安定なリスクが他人の多数のリス クの極小部分の集合という安定的なリスクに変換されることの三つが保険の 要件であるとしている ${ }^{3)}$ 。また，保険法 2 条 1 号は，保険契約を「当事者の 一方が一定の事由が生じたことを条件として財産上の給付…を行うことを約 し，相手方がこれに対して当該一定の事由の発生の可能性に応じたものとし て保険料…を支払うことを約する契約」と定義しているところ ${ }^{4)}$ ，山下友信

3）吉澤卓哉『保険の仕組み』(千倉書房，2006年）。

4）平成 20 年改正前商法629条および673条は，損害保険契約および生命保険契約 を，保険者による損害填補・一定金額の支払の約束に対して，「相手方力之二 其報酬ヨ与フルコトヨ約スル」ものと定義していた。これと保険法 2 条 1 号の 文言とを比較すると，保険法は，保険料が保険事故の発生可能性に応じたもの とされることを要求しており，給付反対給付均等の原則が緩やかな形で要件と されたということができよう（村田敏一「保険の意義と保険契約の類型，他方 
法律の適用・解勫における保険概念の役割

は，保険契約法学においては，これに加えて収支相等の原則と大数の法則の 利用も私保険の要素と一般に考えられているとしている5

典型的な保険が，これらのいずれの点をも具備しており，それに対して保 険法・保険業法等の規律がそのまま適用されることについては，争いはない と思われる ${ }^{6)}$ 。問題となるのは，これらの要素のいずれかを欠く取引に対し て，保険法等がどのように適用されるかという点である。また，逆にこれら の要素をすべて備えている場合には，保険法等が当然に適用されることにな るのかという問題もある。

\section{2. 保険法}

(1) 取引の有効性

まず，保険法の適用の前段階として，ある取引が私法上有効といえるかど うか，民法90条の公序良俗に違反するものとして無効にならないかどうかと いうことが問題となる。たとえば，過去には，デリバティブと賭博との異同 が論じられた。もっとも，この問題について，当該取引が「保険」であるか

との関係」落合誠一＝山下典孝編『新しい保険法の理論と実務』28頁，29-30 頁，35頁 (経済法令研究会，2008年）参照)。この結果として，一律掛金の共 済契約については保険法が適用されないこととなるとの指摘も存在するが（大 串淳子 $=$ 日本生命保険生命保険研究会編『解説保険法』28頁（弘文堂，2008 年)，萩本修編『一問一答保険法』29頁（商事法務，2009年))，そもそも保険 料を保険事故の発生可能性の違いに完全に対応させることは困難であり，コス トの観点から保険料の算定方法を簡易化した場合に，当該契約が保険でないと することが必要であるとも妥当であるとも思われない。適用除外を検討するの であれば，金額についての軽微基準によって対処すべきではないだろうか。な お，平成 20 年改正前商法の下でも，告知義務や危険増加についての通知義務の 存在から，商法は給付反対給付均等の原則も保険の要素と見ているとの指摘も あった（山下友信『保険法』8 頁 (有斐閣，2005年))。

5）山下・前掲（注 4) 6-8 頁。

6）なお，本報告では，保険と共済の関係に関する問題は省略する。この点につ いては, 江澤雅彦「保険と共済の『境界』について」保険学雑誌605号 13 頁 （2009年）を参照。 
否かということは，決定的な意味を持つものではなく，当該取引が公序良俗 に違反するものかどうかについて，当該取引の社会的有用性（たとえば，効 率的なリスク分担の実現）の有無という観点から実質的な検討を行うべきで あろう 7),8)。

（2）保険法の規定の適用

では，有効である取引の契約に保険法の規律を適用すべきかどうかという 問題については，当該取引が「保険」であるか否かということはどういう意 味を持つだろうか。

たとえば，(1)ある者が 1 年以内に死亡したら 1 億円を支払う旨を 1 万円の 受領と引換えに約する取引や，(2)ある者の所有家屋が 1 年以内に火災により 焼失したら 1 億円を 1 万円の受領と引換えに約する取引を，収支相等の原則 が確保されない規模（極端にいえば，1名とだけ）で行う場合，前述の吉澤 や山下の定義によれば，リスクの集積を欠き，保険ではないということにな ると思われる。また，(3)候デリバティブについては，実務上，現実の損害

7）そのような検討の例として，森田果「射倖契約はなぜ違法なのか？」 NBL849号35頁，38－42頁（2007年）を参照。森田は，ある取引の有効・無効 を「射倖契約」という概念により判断しようとするアプローチに対して，問題 点をかえって不明瞭にする危険性があるとも批判している (同42頁)。山下． 前掲（注 2 ）242頁注26，山下・前掲（注 4）24頁も参照。この他，山下と森 田の見解の対比について，神谷高保「被保険利益と利得禁止原則一利得禁止原 則を適用するか否かの判定基準」『中西正明先生喜寿記念論文集 保険法改正 の論点』103頁（2009年，法律文化社）を参照。

8）なお，竹演修「ファイナイト保険の法的性質」立命館法学 310 号210頁， 222 頁（2006年）は，「危険を引き受ける射倖契約性がある契約において，合理的 なリスク処理方法を採らずに有償でリスク移転を行う内容があるときは，相手 方に対して経済的な保障を行える実質のない事業を行うことになるので，場合 によって，詐欺や公序良俗違反の契約となることが考えられ」るとするが，暴 利行為に当たるような場合であればともかく，単に相手方への支払いが滞る可 能性が高いというだけで詐欺を超えて公序良俗に反するとまでは言いがたいよ うに思われる。 
法律の適用・解勫における保険概念の役割

額と関係なく給付がなされるため，（損害）保険ではないと解されているよ うである ${ }^{9)}$ 。そのため，これらの取引は，保険法 2 条 1 号にいう「保険契 約」に該当するとしても，同法 1 条にいう「保険」ではなく，保険法の規定 は適用されないことになりそうである ${ }^{10)}$

しかし，保険法の規定を個別に見ていくと，これらの取引にも適用した方 がよいと思われるものが存在しないわけではない。まず，(1)の例においては， 契約者と被保険者的な地位にある者とが異なっている場合には，モラルリス クを排除し，被保険者的な地位にある者の人格権的利益を保護するため，被 保険者的な地位にある者の同意を要求すべきであるように思われる ${ }^{11)} 。$ 仮に この取引が「保険」ではなく，保険法38条が直接適用されないとしても ${ }^{12)}$, 同条の類推適用の余地までが否定されるわけではなかろう 13)。また，(2)や(3) の例については，現実に発生する損失の額を給付額が上回る可能性があり， 利得禁止原則の適用が問題となる。この点，いわゆる狭義の利得禁止原則は モラルハザードの抑止を目的とするための制度であり，(3に関してはトリガ 一となる事実が気温の変動等，人為的に操作し得ないものであるため，同原

9）山下・前掲（注 4) 22頁。

10）山下友信「保険の意義と保険契約の類型一定額現物給付概念について」『中 西正明先生喜寿記念論文集 保険法改正の論点』 3 頁（2009年，法律文化社） 参照。

11）本文のような取引を，収支相等の原則は確保される規模で，しかし契約者ご とに「保険料」を全く区別せず，給付反対給付均等の原則を充足する意図なく して行う場合にも同様の問題がある。なお，吉澤・前掲（注 3 ） 53頁は，同原 則は保険の要件ではないとしているため, この見解によれば，このような取引 にも保険法の規定が問題なく適用されることになる。

12）吉澤卓哉「保険の仕組みと保険契約法」損保研究69巻 1 号119頁，127頁注 25 （2007年）は，生命保険に相当する生命デリバティブについて，被保険者的 な地位にある者の同意は不要であるが，人格権侵害と賭博の問題は残ると指摘 している。

13）なお，被保険者の同意についての規定は，公序に関する規定であり，強行規 定であるとされている（萩本・前掲（注 4 ）171頁)。 


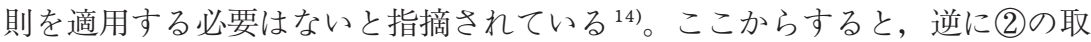
引においてはトリガーとなる事実を人為的に発生させうるため，同原則を適 用ないし類推適用する必要があるとも考えられる ${ }^{15)} 。$

以上のように，個別の規定の類推適用の可能性を考慮すると，ある取引が 「保険」であるのか否かということは，保険法の適用については，重要なも のではあるが16)，それだけで結論を導きうる問題ではないともいえよう ${ }^{17) 。 ~}$

\section{3. 保険業法}

次に，保険業法の適用について検討する。ある事業が「保険業」であると されると，内閣総理大臣からの免許を受けた者でなければ行うことができな くなり (保険業法 3 条 1 項)，己れを行う事業者は組織，経理，事業範囲や 業務内容等に関して特別の規制の適用を受け，金融庁の監督に服するといっ た効果が生じる。そして，これらの公法的な監督規制については，契約法の ような柔軟な解決は取りにくいため，ある事業が「保険」の「引受けを行う 事業」(同法 2 条 1 項) か否かということは，より重要な意味を持ちうるが， その際にも，保険の本質は何かという議論のみならず，これらの規制を適用 する必要性の存否を考える必要があろう。ここでは，前出の(1)や(2)のように

14）山下・前掲（注 4）23－24頁以下を参照。この議論は，人為的に操作し得な い事由を保険事故とする保険についても利得禁止原則の適用を否定する可能性 を含むものである。この点の当否には，本稿では立ち入らない。

15）なお，同原則の強行規定性に関する議論には，本稿では立ち入らない。この 点については，山下・前掲（注 4）389-393頁を参照。

16） ある取引が「保険」であることになると保険法の規定がワンセットで適用さ れることになるのに対して，「保険」ではないということになると個々の規定 ごとに類推適用の是非を検討することになるため，ある取引が「保険」である のか否かは思考経済という観点から意味を持つ（個別の検討の結果として，ほ とんどの規定を類推適用すべきであるというのであれば，その取引はもはや 「保険」であると理解した上で，ただその特質に応じて適用を除外すべき規定 もあると捉えることもできよう)。さらに，裁判所が類推適用という手法を容 易には認めないとすると，実質的な違いも生ずることになろう。

17）山下・前掲（注 4）9頁参照。 
法律の適用・解釈における保険概念の役割

典型的な保険取引の要素を欠く取引に加えて ${ }^{18)}$, 保険取引の要素を具備して いるにもかかわらず保険契約として構成されていない取引への適用を検討す る。

まず，(1)や(2)のように収支相等の原則や給付反対給付均等の原則が確保さ れていない杜撰な運営によって保険のような事業が行われている場合につい ては，典型的な「保険」取引であるとは言いがたい。しかし，規制の実効性 と顧客の保護という観点からは，このような事業を行う業者に対しても監督 を及ぼすべきであり，両原則の充足を厳格に要求するべきではないとの指摘 がなされている19)。

また，典型的な保険取引と同じような効果を持つ取引を「保険」という形 をとらない取引として仕組める場合，たとえば故障・事故発生率に応じた料 金設定の下で行われている(4)家電販売業者による製品保証や(5)会員制の自動 車救援サービスなどについては，これらの事業が「保険業」にあたり，保険 業の免許を取得していない業者は行い得ないのではないかということが問題 となる。この問題は，「保険」とはリスク移転のみを行う取引であり，他の 契約に付随するリスク移転は「保険」ではないという観点（保険の自律性） から整理されることがあるが（4)は保険ではないが，(5)保険でありうると いうことになろう ${ }^{20)}$ ，リスク移転のみを行う取引を「保険」と位置づける 実質的理由が示されるべきであろう。説明の一つとしては，他の契約と密接 に関連したリスクの移転が問題となる場合，当該リスク移転取引を「保険 業」として保険会社に独占させると, 取引コストが増加して非効率であると いうものが考えられる。このような観点からすれば，自動車救援サービスに ついても，それに特化した事業者のリスク評価や損害填補の能力が保険会社

18）（3のデリバティブ取引については，各業法の明文規定（保険業法 98 条 1 項 6 号，銀行法10条 2 項12号14号等）により適用関係が整理されているため，ここ では取り上げない。

19）山下・前掲（注 4） 9-11頁。

20）吉澤卓哉「保険の仕組み」田村祐一郎＝高尾厚＝岡田太志『保険制度の新潮 流』（千倉書房，2008年）50頁。 
保険学雑誌 第 609 号

より高いとすれば，参入の余地を認めた方が競争政策として望ましいとみる ことができよう。もっとも，保険業法の適用に際しては，このような競争政 策的な観点のみならず，顧客保護の観点からの事業者に対する監督の必要性 という観点も重要である。この監督の必要性は，当該業者が約定の債務を履 行せずに破綻した場合の影響の大きさや，契約者にとっての給付の有無の予

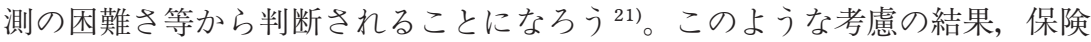
会社以外にも参入を認めることが望ましいが，監督も必要であるということ になった場合，どのように対処するかということは難しい問題である。

なお，(4)や(5)のような取引を保険会社が行うこともできるかという問題も 存在するが，この点については，「保険」として構成することができ，その リスクを保険会社が管理することができるのであれば，他業禁止の趣旨（保 険業法100条）からも，否定する必要はないといえよう。

21）なお，金融庁による「少額短期保険業者向けの監督指針」III - $1-1$ (1)の （注 1 ）および（注 2 ）では，「一定の人的・社会的関係に基づき，慶帅見舞金 等の給付を行うことが社会慣行として広く一般に認められているもので，社会 通念上その給付金額が妥当なものは保険業には含まれない。上記の『社会通念 上その給付金額が妥当なもの』とは，10万円以下とする。」，「予好事故発生に 関わらず金銭を徵収して事故発生時に役務的なサービスを提供する形態につい ては，当該サービスを提供する約定の内容，当該サービスの提供主体・方法， 従来から当該サービスが保険取引と異なるものとして認知されているか否か, 保険業法の規制の趣旨等を総合的に勘案して保険業に該当するかどうかを判断 する。なお，物の製造販売に付随して，その顧客に当該商品の故障時に修理等 のサービスを行う場合は，保険業に該当しない。」とれている。物の製造販 売以外の取引に付随する修理サービス等に関するノーアクションレターとして は，賃貸物件の管理サービス等に付随した空室保証サービスを保険業に該当し ないとは言えないとしたもの (平成18年 4 月 6 日付), 賃貸物件の管理サービ スに付随した借家人退去時の清掃・修繥サービスを保険業に当たらないとした もの (平成19年 4 月 13 日付)，インターネット接続サービスに付随した関連機 器の修理サービスを保険業に当たらないとしたもの（平成21年 7 月 6 日付）が ある (available at http://www.fsa.go.jp/common/noact/kaitou/index. html \#036)。 
法律の適用・解勫における保険概念の役割

\section{4 . 租税法}

また，ある取引が「保険」であるか否かは，当該取引の租税法上の扱いに も影響しうる。たとえば，ある法人が損害保険に加入すると，支払保険料は 全額損金に算入され，保険事故の発生により保険金が支払われると，保険事 故による損害額を損金に算入する一方で受取保険金を益金に参入するという 処理が行われるのが原則である ${ }^{22)}$ 。では，典型的な保険の要素を欠いている にもかかわらず「保険」として構成されている取引についても，常にこのよ うな租税法上の扱いがなされるだろうか。ここでは，いわゆるファイナイト 保険を例に考えてみる。

ファイナイト保険について確定した定義は存在しないが，オーダーメード の長期契約であり，保険会社の投資収益の発生を前提に保険料が割引かれて いる，保険引受リスクが移転する部分と移転しない部分との組み合わせから 構成されている，企業と保険会社間でプロフィットシェアリングが行われ， 保険成績がよければ保険料の一部が返還され，逆に悪ければ追徴されるとい つた特徵を有しているとされる ${ }^{23)}$ 。この取引は，保険引受りスクの移転度合 いが少ない（まったく移転しないものもある）という点 ${ }^{24)}$ ，また同質のリス クが多数存在しない場合にへッジャー間の通時的分散の手法として用いられ ることが多いため ${ }^{25)}$ ，大数の法則によるリスクの分散を利用していない26)こ とがあるという点で，典型的な保険とは異なっている。

特に，租税法との関係では，保険成績がよければ保険料の一部が返還され るため，保険契約者により支払われる金銭は保険料ではなく預け金の性質を

22）渡辺裕泰『ファイナンス課税』194-195頁 (有斐閣，2006年)。

23）吉澤卓哉『企業のリスク・ファイナンスと保険』（千倉書房，2001年）19頁。 吉澤・前掲（注 3 ） 77頁では，「多数年の保険契約で，保険者が引き受けるリ スクが限定的（finite）である代わりに，保険契約当事者間…で保険利益を分 配する仕組みになっている保険」とされている。

24）保険会社には，タイミングリスクと資産運用リスクが移転する。

25）吉澤・前掲（注 3 ） 96頁。

26）竹湏・前掲（注 8 ）210頁。 
持つものであり，当該部分については損金算入ではなく資産計上すべきであ るとされることがある ${ }^{27)}$ 。すなわち，国税不服審判所は，平成17年 7 月 20 日 付の審決により，「損害保険契約における保険料は，通常，保険者が保険期 間中に保険リスクを負担する対価として支払われるものであり，このため， 保険者は，保険事故が発生せず保険金の支払いがない場合でも，受領した保 険料を被保険者へ返還する必要はない」ところ，保険事故不発生時に保険契 約者 (出再者) に返還される分に相当する保険料は「出再者にとって預託金 の性格を有しており，受再者が保険期間に応じて保険リスクを負担する対価 とは認女られない」として，その損金算入を否定している ${ }^{28)}$ 。また，東京地 判平成20年11月27日判例時報2037号22頁は，国内損保会社が海外子会社との 再保険契約を経由してグループ外の海外再保険会社とファイナイト再々保険 契約を締結した事案について，海外子会社に対する支払再保険料については 損金算入を認めつつ ${ }^{29)}$ ，海外子会社とグループ外海外再保険会社との間のフ アイナイト再々保険契約については，傍論として，「たしかに，本件ファイ ナイト再保険契約の再保険料のうちの $\mathrm{EAB}$ 繰入額は，預け金としての性格 を有するものとも解し得る」と述べている ${ }^{30)}$

以上のような扱いが租税法上適切であるのか否かを判断する能力は，筆者

27）租税法上の扱いに言及してはいないが，竹顔・前掲（注 8 ）223頁も参照。 なお，アメリカでは，ファイナイト保険においては保険者への保険引受リスク の移転が限定的である点が問題とされているようである（吉澤・前掲（注23）

53頁，竹溑・前掲（注 8 ）213頁等参照)。日米の着眼点の相違も興味深い。 28）水野忠恒「ファイナイト保険にかかる課税関係のあり方」International Taxation 27巻 9 号50頁（2005年）において紹介されている。

29）その理由としては，本件での再保険契約とファイナイト再々保険契約による 一連のスキームは，保険事故発生時のグループ会社を含めた単年度決算収支の 著しい悪化を回避しつつ利益最大化を図る経済的に合理的なものであるため, ファイナイト再々保険契約とは異なる当事者間における異なる内容の契約であ る再保険契約の再保険料について，ファイナイト再々保険契約の保険料の損金 該当性と同一に判断しなければならない理由はないということが挙げられてい る。

30） 判例時報2037号28頁。 
法律の適用・解勫における保険概念の役割

にはない ${ }^{31)}$ 。本稿の主題にとって参考となるのは，上記の判・審決例で問題 とされているのは，あくまでファイナイト保険の支払保険料について損金算 入が認められるか否かということであり，同保険が「保険」であるのか否か ということではないという点である。損金算入の可否の問題は，まさに租税 法上いかなる場合に損金算入を認めるべきかという点から判断されるべきで あり ${ }^{32)}$ ，たとえば当該ファイナイト保険が大数の法則によるリスクの分散を 利用していないとしても，そのことが租税法上の考察に影響すべきではな い33)。また，逆に租税法上，支払保険料の損金算入が否定されたとしても， そのことは保険業法上，ファイナイト保険が「保険業」に当たらないという ことを意味するものではなく，合理的にリスクを負担できるのであれば，保 険会社が本業として行うことを認めるべきであろう ${ }^{34)}$

\section{5. 小括}

以上のように，法律上，「保険」という概念が当該法律の適用を画する要 件である場合，その解釈に当たっては，一般的に保険の本質は何であるかと いうことのみならず，当該法律の趣旨を考慮する必要があるといえよう。

31）なお，水野・前掲（注28）62頁は，ファイナイト保険において保険事故不発 生時に払い戻される保険料は，発生率を統計的に予測することが困難な損害に ついて，当初の保険料の設定が高額に過ぎたために返却されるものであり，そ のような再計算を内在するのがまさにファイナイト保険であり，この「再保険 料は，たとえ高額であったとしても，単に預託金となるのではなく，やはり， 対象事故‥のリスクに対応したものである」として本文の審決を批判している。

32）もっとも，租税法上，いかなる場合に損金算入を認め，いかなる場合に資産 計上をすべきかという点について，明確な指針が与えられているわけではない ことにつき，中里実「法人課税における保険とデリバティブの境界」『落合誠 一先生還暦記念 商事法への提言』925頁（商事法務，2004年）を参照。

33）満期返戻金のある積立保険については，保険といえるかどうかが議論されて いるが（山下・前掲（注 7 ）36-37頁）, 法人税基本通達 $9-3-9$ は，保険で あるかどうかという議論に立ち入ることなく，積立保険料に相当する金額につ いて資産計上を要求していることも参照。

34） 竹溑・前掲（注 8）224頁。 


\section{III. 典型的な保険と独占禁止法の解釈}

次に，典型的な保険取引について何らかの規定が適用される場合に，保険 の機能を踏まえた解釈をする必要があるかという問題の例として，保険料力 ルテルに対する独占禁止法上の課徴金について，その算定の基準となる「売 上額」(独占禁止法 8 条の 3,7 条の 2 ) の意義が問題となった最判平成 17 年 9 月 13 日民集 59 巻 7 号 1950 頁を検討する。

原審である東京高判平成13年11月30日民集59巻 7 号2009頁は，「営業保険 料のうち現実に保険金の支払に充てられた部分は，保険団体を形成する多数 の保険契約者から集められ，当初の保険契約に基づき，保険団体の構成員で 事故に遭遇した保険契約者又はその指定する被保険者に還元されるもので, 経済的には保険団体内部での資金の移動とみるべきものである。そして，こ の資金の移動を円滑適正に行うことこそが，機械保険等の引受けという損害 保険会社の役務の中心をなすものというべきである」との理解に立って，営 業保険料から支払保険金に充てられた部分を控除した残りの部分を「売上 額」として課徵金額を算定した。最高裁は，この判断を覆し，純保険料と付 加保険料を合わせた営業保険料全額が「売上額」であるとした。

この最高裁判決に対しては，保険会社が提供しているサービスは契約者か ら拠出された純保険料から形成される基金の管理であり，それに対応する 「売上額」は原則として付加保険料であるとする批判が，保険学の立場から なされている ${ }^{35)}$ 。確かに，原審やこの批判説が指摘するように，保険には， 保険契約者間でのリスク分散という側面があり，保険会社は契約者が形成し た共同備蓄の運営というサービスを提供しているという側面があることは否 定できない。

35）井口富夫『現代保険業研究の新展開一競争と消費者利益』63-72頁（NTT 出版，2008年)。井口は，保険によってリスクが保険者に移転されるわけでは なく，リスクは保険契約者間で分散されるのであると指摘する。佐野誠「判 批」損保研究64巻 3 号179頁（2002年），同68卷 1 号283頁（2006年）も参照。 
法律の適用・解勫における保険概念の役割

これに対しては，そもそも独占禁止法が売上額に一定率を乗じて課徵金額 を算定するのは，カルテルにより競争を回避して，高い対価を請求すること による利得を防ぐためであり，競争が制限された商品・役務についての対価 が基準となるところ ${ }^{36)}$ ，この事案でカルテルの対象となったのは営業保険料 全体であり，また，保険会社は，付加保険料率のみならず，純保険料率につ いても競争をしているのであるから，この点を独禁法上考慮しないわけには いかないと指摘されている ${ }^{37)}$ 。しかし，純保険料率がリスクの適切な分散や 運用益により引き下げられるとしても，それも共同基金の管理の一部である と見ることができるかもしれない。

他方で，保険会社は共同備蓄の管理・運営のみを行っているわけではなく， この共同備蓄では保険金を賄いきれない場合には，保険会社は自らの財産か ら保険金を支払う義務を負うのであり，保険会社にリスクがまったく移転し

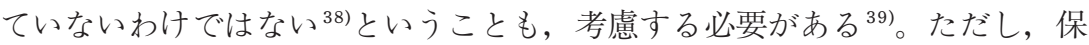
険会社が，共同備蓄の管理運営サービスに加えて，共同備蓄が不足した場合 のリスク負担というサービスを提供しているとしても，その対価が純保険料 全額になるとは限らないとも思われる（場合によっては，この対価も付加保 険料に織り込まれているということもできよう)。

このように見てくると，保険の機能や保険事業に関する理解だけから，保 険会社に対する独占禁止法上の課徵金の算定基準を決定することは困難であ り，同法の課徴金はどのように算定されるべきかということも考える必要が あると思われる。この点, 最高裁は, 課徵金納付命令の機動的な発動のため には課徵金額の算定が容易であることが望ましいという観点から，当該企業 の会計処理上，収益項目に計上されているかどうかという点を基準として

36）川演昇「判批」私法判例リマークス 26 号110頁，112頁 (2003年)。

37）遠藤美光「判批」ジュリスト 1224号253頁，255頁 (2002年)。

38）吉澤・前掲（注 3 ）60頁，75頁。

39）山下・前掲（注 7 ）64頁注50，岡田豊基「損害保険料率カルテルを巡る課徴 金の算定における売上額の意義」神戸学院法学 36 巻 $3=4$ 号571頁，590頁 (2007年)。 
「売上額」を判断することとし，課徴金額としての適切性を個別には検討し

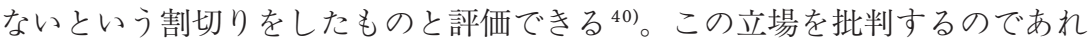
ば，保険の機能とは何かという観点のみからではなく，執行の容易性（これ 自体が重要な目的であることには疑いはない）を重視するあまり，制裁・抑 止効果が過剰 ${ }^{41)}$ まは過少 ${ }^{42)}$ になっていないかという点を問題とすべきであ ると思われる ${ }^{43)}$ 。ただし，理論上の可能性はともかくとして，具体的な事案 について，制裁の過㔂・過少を判断することは容易ではない。

\section{IV. 終わりに}

以上で見てきたように，「保険」という取引・制度をどう捉えるかという 問題は，法律の適用・解釈にとっても議論の出発点として重要なものではあ ク, 出発点により結論が左右されることもありうるが44), 個々の法規定の適 用に際しては，その議論から直接何らかの結論を導きうるとは限らない。典 型的な保険とはどのようなものであり，またどのような機能を有しているの かということを前提とはしつつも，当たり前のことではあるが，当該法規の 趣旨・効果を踏まえて当該法規をいかなる場合に適用すべきかという観点か

40）杉原則彦「判解」ジュリスト1316号166頁，167頁（2006年）参照。

41） カルテルが行われることに社会的意義は全くないとすると, 過剩「抑止」と なることは考えがたいとしても，制裁が過大であると，その後の被制裁者の社 会的に有益な活動が制約されすぎてしまうという問題がある。このマイナスと, 制裁を重くすることによるカルテル行為の減少というプラスを比較することに なろう。

42）仮に，本来は「売上額」＝営業保険料一支払保険金額と解さなければならな いとすると，抑止効果を発揮させるために「売上額」＝営業保険料と読み替え るのは問題があるかもしれないが，後者がことさら不自然な解釈というわけで はなく，このような問題はないと思われる。

43）なお，川演・前掲（注36）112頁は, 課徵金について, 「マークアップ率操作 で対処すべき利得算定の微調整を行うことはそもそも予定されていない」と指 摘している。

44）前注16を参照。 
法律の適用・解勫における保険概念の役割

らの検討が必要であろう ${ }^{45)}$

(筆者は学習院大学准教授)

45）そのため，個別の法律について「保険」という概念が要件として用いられて いる場合であっても，問題となる法規が違えば異なって解釈される可能性は否 定できない。 